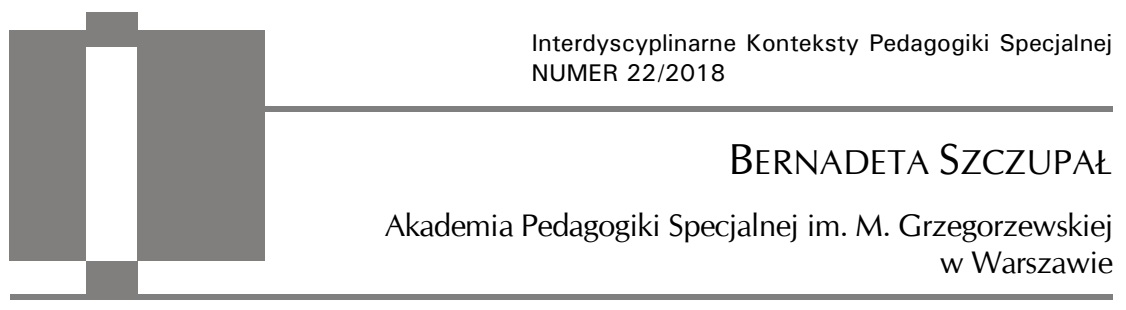

\title{
Godność, codzienność, wsparcie osób starszych z niepełnosprawnością
}

\begin{abstract}
Bernadeta Szczupał, Godność, codzienność, wsparcie osób starszych z niepetnosprawnościa [Dignity, everyday life, support for seniors with disabilities]. Interdyscyplinarne Konteksty Pedagogiki Specjalnej, nr 22, Poznań 2018. Pp. 19-30. Adam Mickiewicz University Press. ISSN 2300-391X. DOI: https://doi.org/10.14746/ikps.2018.22.02

Abstract: The process of ageing is an inevitable life phenomenon in both the individual and social aspects. With the growing life expectancy of humans, the way of living in the old age becomes a challenge in the context of respect for the dignity of the elderly. In this article, I present selected theoretical issues concerning the sense of dignity, everyday life and helplessness of elderly people with disabilities, which is unfortunately often associated with it. I also show the complexity of contemporary problems and expectations and the challenges faced by older people with disabilities.
\end{abstract}

KEY WORDS: Dignity, everyday life, helplessness, support, help, elderly people with disabilities, social welfare homes

\section{Wprowadzenie}

Występujące $\mathrm{w}$ większości państw wysokorozwiniętych zjawisko szybkiego starzenia się ludności jest przyczyną głębokich zmian - politycznych, gospodarczych oraz społeczno-kulturowych. Stale rosnąca populacja osób starszych stanowi zbiorowość niejednorod- 
ną pod wieloma względami, począwszy od stopnia zaawansowania starości, stanu zdrowia i zakresu zachowanej sprawności psychofizycznej, sytuacji socjalnej i ekonomicznej, miejsca zamieszkania, aż po zakres wymaganego wsparcia Doświadczenie starości współcześnie jest przede wszystkim doświadczeniem zmiany i reakcją na zmianę, próbą z nią sobie poradzenia ${ }^{1}$. Wymienione $\mathrm{w}$ tytule artykułu kategorie godności i codzienności osób starszych mają określony wpływ na ich jakość życia, na ich bezradność i konieczność wsparcia. Szczególnie osoby starsze z niepełnosprawnością mogą doświadczać wielu sytuacji godzących w ich poczucie wartości, godności i przynależności społecznej. Starość i niepełnosprawność to zjawiska, którym często towarzyszą zjawiska stereotypii i dyskryminacji. W obecnej rzeczywistości społecznej, pomimo powszechnego uznawania znaczenia godności człowieka, zasadna jest refleksja nad respektowaniem godności osób starszych. Godność osób starszych, wyrażająca się w pragnieniu posiadania szacunku społeczności, w której żyją, może być zagrożona ze względu na pogłębiającą się ich marginalizację. Godne traktowanie człowieka oznacza, że jest on w każdej życiowej sytuacji podmiotem, że ma wolność wyboru, nie może być wykorzystywany, a jego prawa muszą być respektowane².

Sytuacja szybkiego starzenia się ludności niesie także konkretne konsekwencje dla polityki społecznej, grożąc załamaniem się systemów: świadczeń rentowo-emerytalnych oraz usług zdrowotnych i opiekuńczych. Wzrost obciążenia ludności w wieku produkcyjnym ludnością $\mathrm{w}$ wieku nieprodukcyjnym powoduje obniżenie wartości współczynników potencjału wsparcia, określających zdolność, z jaką społeczeństwo może zapewnić nieformalne wsparcie osobom najstarszym. Potrzeby ludzi starych, ich podejście do codzienności, relacje z otoczeniem, wykluczenie, formy aktywizacji, sytuacja życiowa, zdrowotna i ekonomiczna stały się więc w ostatnim czasie niezwykle aktualnym problemem badawczym dla bada-

${ }^{1}$ Z. Strzelecki, J. Witkowski, Przesztość i perspektywy demograficzne Polski, Rządowa Rada Ludnościowa BIP, Warszawa 2009, nr 54, s. 33-60.

2 B. Szczupał, Równość wobec prawa jako jeden z warunków realizacji praw człowieka z niepełnosprawnościa, „Niepełnosprawność - półrocznik naukowy” 2009, nr 1, s. 149-155. 
czy z wielu dyscyplin naukowych. W wielu opracowaniach pomija się jednak aspekt starzenia się osób z niepełnosprawnościami, które w życiu codziennym niejednokrotnie napotykają sytuacje trudne ${ }^{3}$. W życiu codziennym osoby starsze $\mathrm{z}$ niepełnosprawnością szczególnie wymagają pomocy i wsparcia. Starzenie się jest wieloaspektowym procesem, który obejmuje zmiany zarówno fizyczne, jak i psychiczne. Obniżona sprawność fizyczna, słabnący słuch, wzrok, poczucie osamotnienia to tylko niektóre problemy osób starszych ${ }^{4}$. Osoby starsze z niepełnosprawnością oprócz problemów, z którymi zmaga się większość seniorów, muszą zmierzyć się jeszcze z wieloma innymi, specyficznymi ograniczeniami. Osoby starsze z niepełnosprawnością stanowią bardzo zróżnicowaną grupę. Są to zarówno osoby $\mathrm{z}$ niepełnosprawnością wrodzoną lub nabytą we wcześniejszych fazach życia, jak i te, które stały się niepełnosprawne w okresie późnej dorosłości, na skutek ujawnienia się z wiekiem różnych schorzeń prowadzących do obniżenia lub braku sprawności. Pierwsza grupa to osoby, które weszły w fazę starości, już przystosowane do niepełnosprawności, która była obecna w ich życiu od urodzenia. Problemem dla nich mogą być konsekwencje procesu starzenia się nakładające się na trudności wynikające z wcześniejszych dysfunkcji. Natomiast wśród osób z niepełnosprawnością nabytą w późniejszym wieku problemy zdrowotne nakładają się na skutki starzenia się, np. utratę małżonka, zaprzestanie pracy zawodowej, utratę pozycji społecznej, i z tego powodu są odczuwane dotkliwiej ${ }^{5}$. Rosnąca liczba osób starszych, w tym osób z niepełnosprawnością, stanowi poważne wyzwanie dla otoczenia. Konieczne jest zwrócenie uwagi na problemy tej grupy, a także badanie zjawiska starzenia się osób z niepełnosprawnością oraz procesu stawania się osobą niepełnosprawną w okresie starości.

${ }^{3}$ A. Matysiak, Is Poland really 'immune' to the spread of cohabitation?, "Demographic Research" 2009, Vol. 21, s. 215-234.

${ }^{4}$ J. Heitzman, Psychiatria w geriatrii. Wydawnictwo Termedia, Poznań 2018, s. $12-35$.

${ }^{5}$ A. Gutowska, (Nie)petnosprawna starość - przyczyny, uwarunkowania, wsparcie". Interdyscyplinarne Konteksty Pedagogiki Specjalnej" 2015, nr 8, s. 9-33. 


\section{Godność i codzienność osób starszych z niepełnosprawnością}

W obecnej rzeczywistości społecznej, pomimo powszechnego uznawania znaczenia godności człowieka, zasadna jest refleksja nad respektowaniem godności osób starszych. Ważny jest fakt, by osoba poradziła się ze swoją starością i związanym z nią poczuciem własnej godności. Musi ona najpierw sama uporać się z szeregiem spraw oraz pogodzić się ze swoim obecnym stanem. Według Światowej Organizacji Zdrowia wśród osób starszych może występować pewien ciąg przyczynowo-skutkowy: choroba uszkodzenie - niesprawność - inwalidztwo ${ }^{6}$. W sferze deklaracji godność osób starszych jest uznawana za istotną wartość oraz ważny cel działań mających na celu m.in. zapobieganie dyskryminacji. Godność pozostaje zawsze nadrzędnym punktem odniesienia, jest nieporównywalna $\mathrm{z}$ innymi wyznacznikami prawa i nie można jej zamienić na inne wartości. W większości dokumentów legislacyjnych mających zastosowanie do osób starszych osoby te nie występują jako oddzielna kategoria uprawnionych, nie dysponują szczególnymi prawami ze względu na wiek. W Polsce brakuje czytelnych zasad ochrony praw osób starszych (od wielu lat formułowanych $\mathrm{w}$ dokumentach ONZ oraz Rady Europy i Unii Europejskiej) $)^{7}$.

Wewnętrznych uwarunkowań godności człowieka należy upatrywać $\mathrm{w}$ jego osobowości szczególnie w predyspozycjach biopsychospołecznych, wrażliwości moralnej, poczuciu własnej wartości, stylu i jakości życia. Wraz z wydłużeniem ludzkiego życia wyzwaniem, w kontekście poszanowania godności osób starszych, staje się

6 Ibidem.

7 B. Szczupał, K. Chatzipentidis: W poszukiwaniu drogi do emancypacji - godność osoby starszej $i$ ageizm w świetle koncepcji praw człowieka oraz w perspektywie rozwoju wspótczesnego społeczeństwa, "Interdyscyplinarne Konteksty Pedagogiki Specjalnej” 2016, nr 12, s. 99-118. 
sposób przeżywania starości ${ }^{8}$. Wyznacznikiem godnego traktowania jest doświadczanie szacunku od otoczenia. Godne traktowanie człowieka oznacza, że jest on w każdej życiowej sytuacji podmiotem, że ma wolność wyboru i samostanowienia, nie może być wykorzystywany, a jego prawa muszą być respektowane. Godność człowieka wyraża się zapewnieniem mu autonomii, wolności i równości, w tym także $\mathrm{w}$ sferze praw ekonomicznych i socjalnych ${ }^{9}$. Niestety, występują także zjawiska negatywne, które zmieniają sytuację osób starszych, są powodem ich wykluczenia, marginalizacji i dyskryminacji, a więc stanowią zagrożenie podstawowej wartości, jaką jest poczucie własnej godności.

Istnieje wiele przykładów dyskryminacji ludzi starszych, np. negatywne stereotypy dotyczące starości, kult młodości, powszechny brak rzetelnej wiedzy o starości, bezrobocie nasilające konkurencję na rynku pracy, specyficzne potrzeby wieku starszego, procedury, procedury dzielenia publicznych środków finansowych, niskie wykształcenie i osamotnienie ludzi starych, zła organizacja pracy instytucji obsługujących osoby starsze ${ }^{10}$. Kryzys poszanowania godności osób starszych wraz z rozwojem cywilizacyjnym będzie postępował coraz szybciej.

Osoby starsze z niepełnosprawnością codziennie mierzą się z wieloma problemami, które wpływają na ich funkcjonowanie ${ }^{11}$. Są to problemy rodzinne (efekt pustego gniazda), przejście na emeryturę, zmiany związane ze zdrowiem i ciałem, nadmiar wolnego czasu, trudności ekonomiczne i techniczne, zależność od osób trze-

8 I.M. Świtała, Godność osoby starszej w nowej rzeczywistości społecznej. „Roczniki Teologiczne" 2017, z. 10, s. 5-21.

9 T. Romer, Godność człowieka w prawie pracy i pomocy społecznej, [w:] Godność człowieka a prawa ekonomiczne i socjalne. Księga Jubileuszowa wydana w piętnasta rocznice ustanowienia Rzecznika Praw Obywatelskich. Wydawnictwo Biura Rzecznika Praw Obywatelskich, Warszawa 2003, s. 59-83.

10 P. Szukalski, Uprzedzenia i dyskryminacja ze względu na wiek (ageizm) - przyczyny, przejawy, konsekwencje, „Polityka Społeczna” 2004, nr 2, s. 11-15.

11 R. Kijak, Z. Szarota, Starość. Między diagnoza a działaniem. Wydawnictwo Centrum Rozwoju Zasobów Ludzkich, Warszawa 2013. 
cich, rutyna dnia codziennego, pogarszający się stan zdrowia, osamotnienie, pobyt $\mathrm{w}$ domu pomocy społecznej ${ }^{12}$. Wymienione czynniki są jednymi z największych zagrożeń wpływającej negatywnie na poczucie własnej godności osób starszych.

\section{Bezradność osób starszych}

Bezradność może dotyczyć człowieka w każdym wieku. Ma ona swój wymiar jednostkowy - poddana jest wtedy subiektywnej ocenie przez osobę starszą. Równocześnie wyodrębnia się też bezradność $\mathrm{w}$ wymiarze obiektywnym, np. występowanie określonych trudności ludzi starszych $\mathrm{w}$ radzeniu sobie $\mathrm{z}$ poszczególnymi aspektami sytuacji życiowych. Charakterystyczną cechą współczesnej codzienności jest szybko zachodząca zmienność i nieprzewidywalność. Wiąże się to $\mathrm{z}$ dużymi trudnościami w przystosowaniu do częstych zmian i trudnościami $w$ znajdowaniu swojego miejsca w rzeczywistości. Powoduje to zwiększenie zależności od innych. Wystąpienie pierwszych symptomów bezradności u człowieka starszego powinno być sygnałem dla rodziny, sąsiadów, szeroko rozumianej pomocy społecznej do podejmowania konkretnych działań zaradczych ${ }^{13}$.

Dotychczasowe działania na rzecz osób starszych z niepełnosprawnością odznaczają się różną skutecznością. W wielu środowiskach (np. wiejskich) praca socjalna $\mathrm{z}$ osobami $\mathrm{w}$ wieku podeszłym w ogóle nie jest prowadzona. Działania w tym zakresie prowadzone przez instytucje samorządowe, rządowe i organizacje pozarządowe rzadko tworzą spójny system. Każdy podmiot działa według swoich własnych norm i sam decyduje, co jest najważniejsze dla zaspokajania podstawowych potrzeb osób starszych

12 K. Ziomek-Michalak, Znaczenie rodziny $w$ starzeniu się $i$ w starości człowieka. „Roczniki Teologiczne” 2015, z. 5, s. 175-194.

${ }^{13}$ M. Bogusz, S. Ostrowska, Wybrane problemy polityki społecznej i zdrowotnej wobec osób starszych na poziomie lokalnym - sztuka partycypacji. „Prace Naukowe Uniwersytetu Ekonomicznego we Wrocławiu” 2016, nr 450 „Polityka ekonomiczna”, s. 82-90. 
Zdaniem Astrid Tokaj wielowymiarowej bezradności człowieka starszego powinna towarzyszyć wielopłaszczyznowa pomoc ${ }^{14}$. Częstą przyczyną trudności $\mathrm{w}$ okresie starości są tzw. zespoły geriatryczne, np. zaburzenia otępienne, depresja, zaburzenia lokomocji, równowagi, upośledzenia wzroku słuchu i in. Cechą charakterystyczną chorób geriatrycznych jest przewlekłość, wieloprzyczynowość i trudności w leczeniu. Najczęściej ograniczają one aktywność osób starszych, ich mobilność, powodując stopniową utratę niezależności ${ }^{15}$. Ponadto brak autonomii spowodowany wymienionymi zaburzeniami może wywołać przewlekły stres i powstanie innych chorób i zaburzeń. Niepełnosprawność w starości może powodować dodatkowe obciążenie powodujące dysonans pomiędzy stopniem codziennej sprawności a oczekiwaniami osoby starszej oraz ogólne osłabienie organizmu powodujące stan podwyższonego ryzyka rozwinięcia się niekorzystnych zdrowotnie zjawisk, jak łamliwość kości, osłabienie odporności, ogólna słabość psychofizyczna. Wszystkie te czynniki mogą prowadzić do izolacji społecznej, samotności, poczucia osamotnienia i w konsekwencji obniżenia poziomu jakości życia. Niezwykle istotną kwestią jest dążenie do wielokierunkowych zmian w sferze zdrowia, edukacji, obyczajowości, celem zmiany negatywnego wizerunku starości i codziennego, realnego wsparcia tej grupy.

\section{Wsparcie osób starszych}

Starzenie się populacji zmusza pozostałą część społeczeństwa do zmierzenia się z potrzebami charakterystycznymi dla grupy osób starszych. Są potrzeby związane m.in. ze: stylem życia, zdrowiem i opieką, sferą psychospołeczną, aktywnością społeczną, aktywnością zawodową, sytuacją materialną oraz edukacją. Dlatego

14 A. Tokaj, Codzienność, bezradność, pomoc. Trzy kategorie opisu sytuacji życiowej człowieka starszego. „Auxilium Sociale” 2005, nr 3-4, s. 80-95.

15 A. Gutowska, op. cit., s. 9-33. 
do zadań wielu współczesnych instytucji należy zorganizowanie osobom starszym z niepełnosprawnością pomocy związanej m.in. z: poprawą ich sytuacji życiowej, zdrowiem i sprawnością fizyczną, opieką i pomocą w podstawowych czynnościach życiowych, opieką długoterminową i hospicyjną, wsparciem psychologicznym, poczuciem bezpieczeństwa, rekreacją i rozwojem zainteresowań oraz ze wzmacnianiem i wykorzystaniem potencjału osób starszych.

Formy pomocy są ważnym komponentem współczesnej sytuacji osób starszych z niepełnosprawnością. W sytuacjach, w których człowiek nie jest $w$ stanie działać autonomicznie, niezbędne jest zapewnienie ochrony jego godności przez państwo, realizujące $\mathrm{w}$ tym zakresie postanowienia odpowiednich aktów legislacyjnych poprzez odpowiednią politykę społeczną ${ }^{16}$. Niestety współczesna sytuacja społeczna może być źródłem barier w dostępie do ważnych dóbr i wartości oraz stanowić zagrożenie dla zaspokajania potrzeb przez osoby starsze, może też narażać je na dyskryminację zwielokrotnioną (np. miejsca zamieszkania, wieku, płci i niepełnej sprawności) ${ }^{17}$. Wymienione bariery mogą często prowadzić do konieczności pomocy i wsparcia osób starszych.

W Polsce dominującą formą jest opieka rodzinna, zaś w sytuacji braku rodziny bądź jej niewydolności opiekuńczej lub osłabienia więzi rodzinnych do udzielania pomocy zobowiązane są formalne organizacje lub instytucje opiekuńcze ${ }^{18}$. Do obszarów wsparcia i pomocy społecznej, których adresatem są osoby starsze, należą: ochrona zdrowia, pomoc społeczna, ubezpieczenie społeczne i warunki socjalne. Wsparcie to może być udzielane w pomocy środowiskowej miejsca zamieszkania tych osób lub pomocy instytucjonalnej, realizowanej poprzez domy pomocy społecznej będące placówkami

16 B. Mikołajczyk, Międzynarodowa ochrona praw osób starszych, Wydawnictwo Wolters Kluwer Polska Sp. z o.o., Warszawa 2012.

17 B. Szatur-Jaworska, Uczestnictwo osób starszych w sferze publicznej, „Biuletyn RPO" 2008, nr 65, s. 115-121.

18 Rajczykowska M., Środowisko terapeutyczne nowe podejście do projektowania domu seniora, „Społeczeństwo i Edukacja. Międzynarodowe Studia Humanistyczne” 2015, nr 2, s. 173-180. 
stałego lub czasowego pobytu tych osób ${ }^{19}$. Obie formy wsparcia, instytucjonalna i pozainstytucjonalna, powinny być komplementarne i nie mogą ograniczać się do fragmentarycznych oddziaływań $\mathrm{w}$ wybranych obszarach, resortach, systemach.

Zdaniem A. Tokaj podstawowy kierunek wszelkich działań wspomagających dla osób starszych musi zmierzać w kierunku podtrzymania aktywności i samodzielności tej grupy osób dla zaspokajania codziennych potrzeb życiowych oraz integracji z najbliższym środowiskiem. Polityka społeczna wobec osób starszych powinna uwzględniać trzy podstawowe zasady: subsydiarności, kompleksowości oceny potrzeb i lokalności ${ }^{20}$. Zasady te wskazują, że jakość życia osób starszych jest wypadkową równomiernego rozłożenia odpowiedzialności zarówno na państwo, jak i na środowisko lokalne oraz rodzinę. Głównym podmiotem odpowiedzialnym za realizację polityki lokalnej wobec ludzi starszych i starości jest gmina. Jej podstawowe znaczenie $\mathrm{w}$ tym zakresie wynika ze szczególnej pozycji, jaką gmina zajmuje $\mathrm{w}$ strukturach administracji publicznej i uprzywilejowanego miejsca wśród jednostek samorządu terytorialnego. Działania powiatu i województwa mają charakter uzupełniający i wspomagający (w perspektywie lokalnej i regionalnej) inicjatywy podejmowane na szczeblu gminy.

Warto również zauważyć, że coraz częściej osoby starsze z niepełnosprawnością traktowane są podmiotowo. Pod uwagę brane są ich potrzeby. Osoby starsze silnie odczuwają też potrzebę szacunku, wzmocnienia ich poczucia godności i użyteczności. Potrzeby te mogą realizować dzięki pomocy różnorodnych instytucji, takich jak np.: domy dziennego pobytu, uniwersytety trzeciego wieku, kluby seniora, organizacje samopomocowe, organizacje kulturowe, wolontariaty, rady seniorów, społeczne banki czasu²1. Aktywność osób

${ }^{19}$ W. Borczyk, D. Jachimowicz, W. Nalepa, Partycypacja osób starszych w życiu publicznym - wybrane zagadnienia, Ogólnopolska Federacja Stowarzyszeń Uniwersytetów Trzeciego Wieku, Nowy Sącz 2015.

${ }^{20}$ A. Tokaj, op. cit., s. 80-95.

${ }^{21}$ S. Scherger, J. Nazroo, P. Higgs, Leisure activities and retirement: do structures of inequality change in old age?, "Ageing and Society” 2011, 31, s. 146-172. 
starszych spełnia przede wszystkim potrzebę bycia użytecznym i potrzebnym, daje poczucie spełnienia, niezależności, umożliwia przekazywanie mądrości życiowej i nagromadzonego doświadczenia 22 . Osoby starsze mają wtedy mają zapewnione poczucie stabilizacji, równowagi, bezpieczeństwa, leczenia, rehabilitacji i terapii. Natomiast brak takiej aktywności może powodować utratę akceptacji ze strony otoczenia, czego konsekwencją jest samotność i brak poczucia własnej godności.

\section{Podsumowanie}

Rosnąca liczba osób starszych, w tym osób z niepełnosprawnością, jest istotnym wyzwaniem społecznym, gospodarczym i politycznym. Współczesna rzeczywistość stwarza wiele ograniczeń i powoduje kryzysy egzystencjalne, które pogarszają jakość życia osób starszych oraz poszanowanie ich godności. Procesu starzenia się nie można zahamować, ale można go modyfikować, by stał się dobrym okresem życia. Niezbędne jest więc zwrócenie uwagi na codzienne problemy tej grupy, a także badanie zjawiska starzenia się osób z różnymi niepełnosprawnościami oraz procesu stawania się osobą z niepełnosprawnością w okresie starości ${ }^{23}$. Wydłużenie ludzkiego życia nie zawsze jest połączone $\mathrm{z}$ satysfakcjonującą sprawnością psychofizyczną i samodzielnością. Istotne znacznie ma również zwracanie uwagi na poczucie godności osób starszych, które pomaga ukierunkować ich życie pomimo zmiennych okoliczności, motywuje, wnosi poczucie sensu istnienia, wyznacza drogowskazy moralne, krystalizuje tożsamość, wzmacnia wierność ideałom i wartościom. Wyznacznikiem godnego traktowania jest doświadczanie szacunku ze strony najbliższego otoczenia. Niezbędne jest podmiotowe traktowanie osoby starszej $\mathrm{z}$ niepełno-

${ }^{22}$ M. Posłuszna, Aktywność rodzinna i społeczna osób starszych, „Nowiny Lekarskie" 2012, 81, 1, s. 75-79.

${ }^{23}$ A. Gutowska, op. cit., s. 9-33. 
sprawnością, przyznające jej prawo do godności, szacunku, własnej odrębności, decydowania o sobie, przeciwdziałanie marginalizacji społecznej oraz edukacja społeczna mająca na celu przezwyciężanie stereotypów wobec osób starszych. Istotne jest promowanie postaw urzeczywistniających szacunek dla godności, wolności i równości człowieka starszego. W tym okresie życia bardzo ważne jest wsparcie i pomoc, ale jeszcze bardziej zrozumienie, uważność, umiejętność słuchania i szacunek. Dzięki takim postawom osoby starsze $\mathrm{z}$ niepełnosprawnością chętniej partycypują w życiu społecznym, w miarę swoich możliwości działają w różnych organizacjach, rozwijają się i mają chęć bycia aktywnymi.

\section{Bibliografia}

Bogusz M., Ostrowska S., Wybrane problemy polityki społecznej i zdrowotnej wobec osób starszych na poziomie lokalnym - sztuka partycypacji. "Prace Naukowe Uniwersytetu Ekonomicznego we Wrocławiu” 2016, nr 450 „Polityka ekonomiczna”, s. 82-90.

Borczyk W., Jachimowicz D., Nalepa W., Partycypacja osób starszych w życiu publicznym - wybrane zagadnienia, Ogólnopolska Federacja Stowarzyszeń Uniwersytetów Trzeciego Wieku, Nowy Sącz 2015.

Gutowska A., (Nie)petnosprawna starość - przyczyny, uwarunkowania, wsparcie. „Interdyscyplinarne Konteksty Pedagogiki Specjalnej" 2015, nr 8.

Heitzman J., Psychiatria w geriatrii, Wydawnictwo Termedia, Poznań 2018.

Kijak R., Szarota Z., Starość. Między diagnozą a dziataniem, Wydawnictwo Centrum Rozwoju Zasobów Ludzkich, Warszawa 2013.

Matysiak A., Is Poland really 'immune' to the spread of cohabitation?, "Demographic Research" 2009, Vol. 21.

Mikołajczyk B., Międzynarodowa ochrona praw osób starszych, Wydawnictwo Wolters Kluwer Polska Sp. z.o.o., Warszawa 2012.

Posłuszna M., Aktywność rodzinna i społeczna osób starszych. "Nowiny Lekarskie” 2012, $\mathrm{nr} 81,1$.

Rajczykowska M., Środowisko terapeutyczne nowe podejście do projektowania domu seniora, „Społeczeństwo i Edukacja. Międzynarodowe Studia Humanistyczne” 2015, nr 2.

Romer T., Godność człowieka w prawie pracy i pomocy społecznej, [w:] Godność człowieka a prawa ekonomiczne $i$ socjalne. Księga Jubileuszowa wydana w piętnasta rocznicę ustanowienia Rzecznika Praw Obywatelskich, Wydawnictwo Biura Rzecznika Praw Obywatelskich, Warszawa 2003. 
Scherger S., Nazroo J., Higgs P., Leisure activities and retirement: do structures of inequality change in old age?, ,Ageing and Society" 2011, 31.

Strzelecki Z., Witkowski J., Przeszłość i perspektywy demograficzne Polski, Warszawa, Rządowa Rada Ludnościowa, Biuletyn 2009, nr 54.

Szatur-Jaworska B., Uczestnictwo osób starszych w sferze publicznej, "Biuletyn RPO” 2008, nr 65.

Szczupał B., Równość wobec prawa jako jeden z warunków realizacji praw człowieka $z$ niepełnosprawnością, Niepełnosprawność - półrocznik naukowy, nr 1: Teoretyczne i metodologiczne konteksty pedagogiki specjalnej, Fundacja Rozwoju Uniwersytetu Gdańskiego, Gdańsk 2009.

Szczupał B., Chatzipentidis K., W poszukiwaniu drogi do emancypacji - godność osoby starszej $i$ ageizm $w$ świetle koncepcji praw cztowieka oraz w perspektywie rozwoju wspótczesnego społeczeństwa, „Interdyscyplinarne Konteksty Pedagogiki Specjalnej" 2016, nr 12.

Szukalski P., Uprzedzenia i dyskryminacja ze względu na wiek (ageizm) - przyczyny, przejawy, konsekwencje, „Polityka Społeczna” 2004, nr 2.

Świtała I.M., Godność osoby starszej w nowej rzeczywistości społecznej. „Roczniki Teologiczne" 2017, z. 10.

Tokaj A., Codzienność, bezradność, pomoc. Trzy kategorie opisu sytuacji życiowej człowieka starszego. „Auxilium Sociale” 2005, nr 3-4.

Ziomek-Michalak K., Znaczenie rodziny w starzeniu się i w starości człowieka. „Roczniki Teologiczne" 2015, z. 5. 